の必要性が甯感される。

\section{6. あとがき}

ATC 自動化システムについて，簡単に紹介したが， このシステムの整備は，增大する航空交通を安全に円 滑に管制するためには必須のあのと考えられる，管制 自動化は好理能力の增強のみならず，管制方式の標準 化，人的エラーの減少等から安全性が飛躍的に向上す るという重要な利点をむたらすむのと考えられる。

最後に一言申し上げたいととは，現在行なわれてい る管制自動化は，管制官の判断資料を如何に早く，正 確に管制官に提供するかであり，最終的な判断は人間 である管制官が行なうあのである。したがってこのシ ステムはあくまでも管制官の道具であるととが基本と なっている. 一般的に自動化の用語は，化学工場のプ ロセス・コントロールのように計算譏が大半の業務を 人間の代わりに行なう場合に用いられるあのであり， ATC の場合は誤解のないように部内では，“航空交通 管制情報処理システム”の用語を使用している。

わが国の航空界の発展の一端をになう管制官の一員 として，一日あ早く管制施設の近代化のために，シス テムの導入が行なわれることを願いつつ筆をおきた
参文献考

1) ICAO Bulletin (Aug. 1971), CAUTRA IV Automated ATCC operational.

2) Interavia (Sept. 1971), UK Military and Civil Air Traffic Control in Harmony.

3) FAA: The National Aviation System Plan Ten Years Plan 1972-1981 (Mar. 1971).

4) FAA: Design for the NAUS (1962).

5) FAA: System Description National Air Space System en Route Stage A (May 1968).

6) FAA : FAA Specification for Modularly Expandable Arts III (Tracon "C") Beacon Tracking Level System (Apr. 1971).

7) 岡田他：電気通信学会研究資料, SANE 67-1 (196704), 我国の ATC 自動化計面.

8) Aviation Week \& Space Technology, ARTS-3 Readied for FAA Service, (Jan. 1971).

9) Aviation Week \& Space Technology, (May 1971).

10) FAA: Use of Computers in air Traffic Control (June 1970)

11) FAA : ARTS III System Description (Aug. 1970).

12) Sperry Rand: Engineering Review, (Air Traffic Control Part I-1971).

13) ICAO: DOC, 4444-RAC/501/10. Procedures for Air Navigation Service Rules of the Air and Air Traffic Services Attachment D Guidance Material on the Application of Automation in ATC.

\title{
衝撃波を伴わない遷音速翼型について (2)* On Shock-Free Transonic Aerofoil Sections
}

重 見 孝**・高 梨進**

Takashi ShIgemi and Susumu Takanashi

\section{8. 数值的ホドグラフ法}

同しくホトグラフ法により翼のまわりの shock-free の流㣗を求めて，NIEUWLAND につづいて成功を収め たのは KORN ${ }^{23)}$ である. 彼の手法は，以前に GARABEDIAN $^{24)}$ が超音速流中の針頭物体が造る detached shock の後方の流れを求めるため案出した“複素空間 の特性曲線法” の态用である，速度成分 $u, v$ が独立 変数, また物理面での座標 $x, y$ が従属変数となるよ うに压縮性流の基整式を変換 (これもホドグラフ変换) すると，次の線型一階連立偏微分方程式となる（付録 (I) 参炤).

$$
\begin{aligned}
& \left(a^{2}-u^{2}\right) y_{v}+2 u v x_{v}+\left(a^{2}-v^{2}\right) x_{u}=0 \\
& -y_{u}+x_{v}=0
\end{aligned}
$$

変数分離にたよらないから(3)式のように流机関数 $\Psi$

* 昭和 46 年 11 月 18 日原稿受理

** 航空宇宙技術研究所
を用いず，独立変数にも $(q, \theta) や(\tau, \theta)$ を用いない． つぎに上式に特性変換を行なう。すすねち次の特性 をすつ characteristic coordinates $\xi, \eta$ を導入する. $\partial / \partial \xi=\partial / \partial v+\lambda+\partial / \partial u, \quad \partial / \partial \eta=\partial / \partial v+\lambda-\partial / \partial u$,

$$
\begin{aligned}
& \text { ここに } \lambda_{-,} \lambda_{+} \text {は } \\
& \quad \lambda_{ \pm}=\left\{u v \pm a \sqrt{q^{2}-a^{2}}\right\} /\left(a^{2}-u^{2}\right)
\end{aligned}
$$

(ただし $a$ は局所音速) で表わされる characteristic directions である.すると

$$
\begin{aligned}
& u_{\xi}=\lambda_{+} v_{\xi}, \quad u_{\eta}=\lambda_{-} v_{\eta} ; \\
& y_{\xi}+\lambda-x_{\xi}=0, \quad y_{\eta}+\lambda_{+} x_{\eta}=0
\end{aligned}
$$

なる，characteristic coordinates を用いた基礎方程式 加得られる，( $(x, y)$ 面または $(u, v)$ 面で $\xi=$ 一定， および $\eta=一$ 定の曲線群はそれぞれ family を作り， これらの曲線を characteristics と呼ぶ。

超音速 $(q / a>1)$ では $\lambda \pm$ は実数で，式は双曲型で ある. 互音速 $(q / a<1)$ では $\lambda_{+}$と $\lambda$ - とは共役複素 
数で，式は㮁円型となる．前者の場合は衆知のどとく 実数籍团で特性曲線法が適用でき，初期值が与えられ れば流れが計算できる、一般に各 family に属する characteristic 一本ずつ（たとえば $\xi=\xi_{0}$ と $\left.\eta=\eta 0\right)$ の上で初期值 (characteristic initial data) が与えられ る場合を characteristic initial value problem という. (KORN の方法もこれに属する.)

しかし棈円型の場合でも，(92)，(93）式の係数は解 析的に与えられているから，uとvとを複素数へ拡張 することができる（すると独立变数は四次元空間へ拉 がるととになる). 初期值す，あしそれが解析的に与 えられていれば，この複素空間に延長するととができ る. 複素空間では微分方程式の型の概念は重要でなく はり，亜音速でも特性曲線法を形式的に適用するとと ができる.

$u, v$ を複素数領域に㹡張したから $\xi, \eta$ あまた複素 数で, 各 characteristic は四次元空間内の (二次元) 面である. 特性変换の singularity は $q=a_{*}$ （音速の 個所) で現われる。これを complex sonic line と呼 ぶが，実はこれも $u, v$ 空間内の（二次元）面である. 一般に複素ホドグラフ空間内の任意の点 $(u, v)$ を通る characteristics は $\xi, \eta$ 二つである(したがってその 点をしばしば $(\xi, \eta)$ と呼ぶ）が， complex sonic line 上では(95)式から両 characteristic directions が合致 する. 流れを亜音速加超音速へ延長するさいての complex sonic line が重要な役割をする.

KORN の方法では翼型まわりの流れをホドグラフ上 の特性曲線法により characteristic initial value problem で解く，計算の実行には差分法を用いる．しか し翼のまわりの流れのホドグラフには前各節に述へた とおり singularity があるからまずとの singularity を解析的に求め (singular solution), 残りの regular 部分 (regular solution) を差分法で求め，両 solution を加え合わせる(原方程式が線型なることを利用).

Singular solution を特性曲線法に便利な形で求めるに はまた非厌縮流から出発する、とてで $\eta(\zeta)=(1-\zeta)^{1 / 2}$

なる新変数を導入する. あとでとのクは一つの characteristic であることが分かる。循環なしの円柱まわりの流れ では(12)式より

$$
z\left(=(1-\zeta)^{-1 / 2}=1 / \eta \quad\right. \text { (円柱) }
$$

であるが，てれを拡張して

$$
z=1 / \eta+f(\eta)
$$

$(f(\eta)$ は流れの領域で regular な, $\eta$ の関数) とすればか なり一般的な物体形状を表わせるであろう．例えば棈円柱 まわりの流れ（第 11 図参照）は(26)と(27)とより $z^{\prime}$ を消 去し，特に $\beta=1 / \sqrt{1-\varepsilon}$ とおき，さらに(98)よりしを》 で置換えると，

$$
\begin{aligned}
z & =\frac{1}{\eta}\left(1+\frac{\varepsilon}{1-\varepsilon} \eta^{2}\right)^{1 / 2}+\frac{\varepsilon \eta}{1-\varepsilon}\left(1+\frac{\varepsilon}{1-\varepsilon} \eta^{2}\right)^{-1 / 2} \\
& \equiv 1 / \eta+g(\eta) \quad(\text { 梢円柱) }
\end{aligned}
$$

となり(100)の形であることが分かる（の）は(101)の右辺 加ら $1 / \eta$ を引いた regular 部分である).

一方，非王縮流の基礎式は(92)，(95)において $a \rightarrow \infty$ 之 すればよいから, characteristic directions は

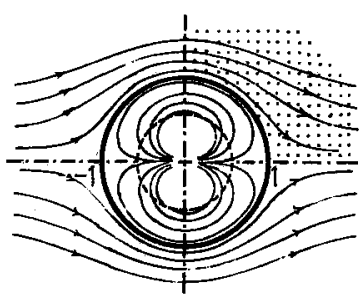

2a) z'-plane

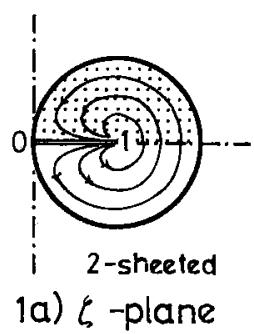

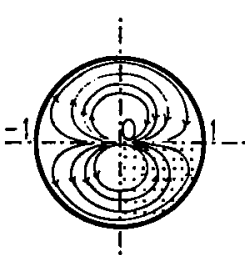

1b) $\eta$-plane

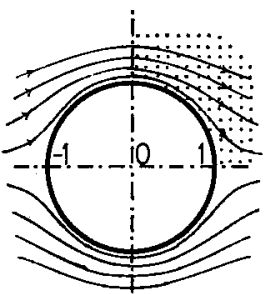

1c) $1 / \eta$-plane
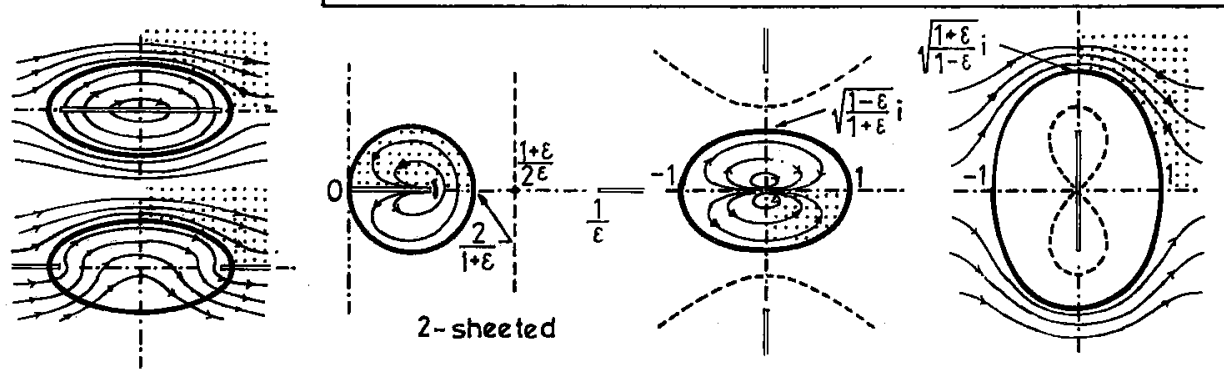

2b) z-plane

2c) C-plane

2d) $\eta$-plane

2e) $1 / \eta$-plane

第11 四 円柱 (1 a), 1 b), 1 c) または $2 \mathrm{a})$ )，棈円柱 $(2 \mathrm{~b}) \sim 2 \mathrm{e})$ ) まわりの非任縮流を $\left(z^{\prime}\right), z, \zeta, \eta, 1 / \eta$ 面で示 す. 流線を仲介として各面の写像関係の概念が得られる. なお $2 b$ ) の棈円の半長軸; 半短軸の長さ は, 8 節の写像 $(\beta=1 / \sqrt{1-\varepsilon})$ では $(1+\varepsilon) / \sqrt{1-\varepsilon} ; \sqrt{1-\varepsilon}$ であり，4節の写像 $(\beta=1)$ では $(1+\varepsilon)$; $(1-\varepsilon)$ である. 


$$
\lambda_{ \pm}= \pm i
$$

である.すると(94)式の形から

$$
\zeta=u-i v, \bar{\zeta}=u+i v
$$

は一対の characteristic coordinates を成すとと加分か る. ある characteristic coordinate $の$ 任意関数もまた characteristic coordinate であるから，(98) 式で定義し た $\eta(\zeta)=(1-\zeta)^{1 / 2}$ もとの一つて，(94)，(96)，(97)式中の に充当してよい，とれと一対をなす $\boldsymbol{\varepsilon}$ には

$$
\varepsilon=(1-\bar{\zeta})^{1 / 2}
$$

を用いるととにする，

よってもし楕円柱まわりの非王縮流を characteristic initial value problem として解こうとするなら，(96)， (97), (103) を characteristic initial data:

$$
\begin{aligned}
& \eta=\eta_{0} \text { 上で } x=g\left(\xi, \eta_{0}\right) \\
& \xi=\xi_{0} \text { 上で } x=g\left(\xi_{0}, \eta\right) \\
& g(\xi, \eta)=\frac{1}{\eta}\left(1+\frac{\varepsilon}{1-\varepsilon} \eta^{2}\right)^{1 / 2}+\frac{\varepsilon \eta}{1-\varepsilon}\left(1+\frac{\varepsilon}{1-\varepsilon} \eta^{2}\right)^{-1 / 2} \\
& -\frac{1}{\eta}
\end{aligned}
$$

について解き（ちちろんとのとき $x=g(\xi, \eta), y=-i g(\xi, \eta)$ がその解として数値的に得られるであろう)， その解 $x, y$ に対し， $x$ のの実数部には singular solution $1 / \eta$ の実数 部を， $y$ の実数部には $1 / \eta$ の虚数部を加えて，最終的に楕 円柱まわりの非王宿解か得られる。

以上の誐論を王縮性の場合に拡張しよう。いま

$$
q=\left(u^{2}+v^{2}\right)^{1 / 2}, \theta=\tan ^{-1}(v / u)
$$

で定義される極座標系 $(q, \theta)$ (いま一般にはどちらあ 複素数) を藥入すると， $\bar{\zeta}=q e^{i \theta}, \zeta=q e^{-i \theta}$ と表わさ れるから，とれらに対応する住縮流の characteristic coordinates $の 一$ 対として $m=e^{s-s_{1}} e^{i \theta}, n=e^{s-s_{i}} e^{-i \theta}$ を試みる，付録 $(\mathrm{A} \cdot 29)$ より $s=\lambda+\sigma$ ( $\sigma$ : 常数) で あるから $s-s_{1}=\lambda-\lambda_{1}$ ，とこに $s_{1}, \lambda_{1}$ は一般流 $q=1$ (亜音速) における $s, \lambda$ の值で，実数である， $e^{-\lambda_{1}}$ $\left(=e^{\sigma-s_{1}}\right) \equiv C$ (実数) として,

$$
m=e^{s-s_{i}} e^{i \theta}=C e^{\lambda+i \theta}, n=e^{s-s_{1}} e^{-i \theta}=C e^{\lambda-i \theta}
$$

と書ける．まず $q, \theta$ が実数の範囲では，覀音速では (A.26) で定義される入は（したがって $s$ あ）実数で， (A.31) より $a \rightarrow \infty$ のとき $m, n$ は $\bar{\zeta}, \zeta$ となる.

$$
\lim _{a \rightarrow \infty} m=\bar{\zeta}=q e^{i \theta}, \lim _{a \rightarrow \infty} n=\zeta=q e^{-i \theta}
$$

次に，超音速では(A.26)より入は虚数となるからこ れを $i \Lambda$ と書く ( 1 は実数，(A.27)参照)，とのとき (108)式より， $m$ 一定なら $\Lambda+\theta=$ 一定； $n$ 一定なら $\Lambda-\theta=$ 一定だから $m, n$ は real な特性曲線法での characteristic coordinates $の 一$ 対となる(付録(A-28) 参照). 以上の関係を $q, \theta$ が複素数の場合に搪張し， やはり $m, n$ は亚，超音速を通じて，非圧縮流の $\bar{\zeta}, \zeta$ に対応する characteristic coordinates の一対亡考え てよい，さらにとこでは非代縮流と相仪に，

$$
\xi=(1-m)^{1 / 2}, \eta=(1-n)^{1 / 2}
$$

(いずれあ一般に複素数)を characteristic coordinates として用いるととにする。

循環なしの王縮流では基礎式（97）の解は，やはり非
压縮流からの類推で (100)式の同粎の形:

$$
z=Z^{\mathrm{I}} / \eta+Z^{\mathrm{II}}
$$

が期待できる( $Z^{\mathrm{I}}, Z^{\mathrm{II}}$ は一般的には $\xi, \eta$ の関数で， $\xi=\eta=0$ で regular). そこで次の形を仮定しょう.

$$
\begin{aligned}
& x=\operatorname{Re} .\left(X^{\mathrm{I}}(\xi, \eta) / \eta+X^{\mathrm{I}}(\xi, \eta)\right] \\
& y=\operatorname{Re} .\left[Y^{\mathrm{I}}(\xi, \eta) / \eta+Y^{\mathrm{II}}(\xi, \eta)\right]
\end{aligned}
$$

ここに $X^{i}, Y^{i}(i=\mathrm{I}, \mathrm{II})$ は $\xi=\eta=0$ で regular であ

る. (112) を基整方程式 (97) に入れ次の関係が出る.

$$
\begin{aligned}
& Y_{\xi}^{\mathrm{II}}+\lambda_{-} X_{E}^{\mathrm{II}}=-\left(Y_{\xi}^{\mathrm{I}}+\lambda_{-} X_{\xi}^{\mathrm{I}}\right) / \eta \\
& Y_{\eta}{ }^{\mathrm{II}}+\lambda_{+} X_{\eta}{ }^{\mathrm{II}}=\left(Y^{\mathrm{I}}+\lambda_{+} X^{\mathrm{I}}\right) / \eta^{2} \\
& -\left(Y_{\eta}^{\mathrm{I}}+\lambda_{+} X_{\eta}{ }^{\mathrm{I}}\right) / \eta
\end{aligned}
$$

regular solution $X^{\mathrm{II}}, Y^{\mathrm{II}}$ が得られるためにはこれら の布扨が regular である必要がある.よって characteristic $\eta=0$ 上て

$$
\left.\begin{array}{l}
Y_{\xi}^{\mathrm{I}}+\lambda-X_{\xi}^{\mathrm{I}}=0 \\
Y^{\mathrm{I}}+\lambda_{+} X^{\mathrm{I}}=0 \\
Y_{\eta}^{\mathrm{I}}+\lambda_{+} X_{\eta}^{\mathrm{I}}=0
\end{array}\right\}(\eta=0 \text { 上で })
$$

(116)より $Y_{\eta}{ }^{\mathrm{I}}+\lambda_{+} X_{\eta}{ }^{\mathrm{I}}+\left(\lambda_{+}\right)_{\eta} \cdot X^{1}=0$, これと (117) よ b,

$$
\left(\lambda_{+}\right)_{\pi} \cdot X^{1}=0 \quad(\eta=0 \text { 上で })
$$

いま取扱う上下対称翼で狧環なしの場合は (110) 式よ り, $n$ は $\eta$ の偶関数だから， $\eta=0$ 上で $\left(\lambda_{+}\right)_{\eta} \equiv\left(\lambda_{+}\right)_{n}$ $\cdot(d n / d \eta)=0$, よって (118)は自ら満たされる.

$X^{1}(0,0)=1$ ，すなわち解が無限遠点 $\xi=\eta=0$ で非 纴縮流と一致するようにきめると，とれと(115)，(116) とから $X^{\mathrm{I}}(\eta=0)$ に関する一階線型微分方程式が生: じ，その解は次のように閉じた形で書ける.

$$
X^{\mathrm{I}}(\xi, 0)=\exp \left\{\int_{0}^{\xi}-\left[\frac{\left(\lambda_{+}\right)_{\xi}}{\lambda_{+}-\lambda_{-}}\right]_{\eta=0} d \xi\right\}
$$

これは SIMPSON 法則のような簡単な求皘法で数值計 算できる（119）を満足する任意の $X^{\mathrm{I}}$ とそれに対応 する $Y^{\mathrm{I}}$ とで singular solution を組立ててよいから， $X^{1}$ は $\xi$ のの関数とすることができる,すなわち $X^{\mathfrak{l}}(\xi, \eta)=(119)$ 式の右辺

$X^{\mathrm{I}}, Y^{\mathrm{I}}$ が決定されると(113)，(114)の右包は既知之 なりとれらは $X^{\mathrm{II}}, Y^{\mathrm{II}}$ に関する非同次の連立線型偏 微分方程式となる，これらと(96)式とを差分近似式に 直して MASSAU の方法 ${ }^{25)}$ で数值皘分する. 複素数計 算上なる.

Characteristic initial value problem として characteristic surfaces $\xi=\xi_{0}, \eta=\eta_{0}$ 上で解析的データを与 える（特暴点 $\eta=0$ の付近は計算上の困難が生じるか ら避けた方がよい)， $\xi=\xi_{0}$ 面上に $\eta=\eta_{0}$ 加ら出発す る一つの characteristic path: $\eta=\eta(\nu)$ をとり, その grid 点を $\eta_{0}, \eta_{1}, \cdots, \eta_{N}$ とする. 同様に $\eta=\eta_{0}$ 面上で 6 path: $\xi=\xi(\mu)$ を選ひ， その上に grid 点をとる. これら $\xi_{0}, \eta_{0}$ 面上での $u, v$ の值は characteristic coordinates とホドグラフ変数との関係が (108), (110) 式 
で閉じた形で分かっているから計算できる， $\xi_{0}, \eta_{0}$ 両 面で関数 $X^{\mathrm{II}}$ を初期値として与えれば，その上での $Y^{\mathrm{II}}$ は (114) または (113) 式をそれぞれ積分して求め られる。

$\mu, \nu$ は arc-length parameter で実数であるからら， 上記の初期值から得られる解の領域は $(\mu, \nu)$ 平面を描 いて視察できる(第 12 図)。解の domain は $\xi_{0}, \eta_{0}$, $\xi_{N}, \eta_{N}$ の四 characteristics Kかてまれた矩形である. 初期値より出発して解の domain 内人次々と MASSAU の方法を進めてゆく様子を第 12 图に示す。

物理的意味のあるのは $u, v$ が装数の解のみである から，それが生ずるよう characteristic path を選ば なければならない，(108)式を調べると， $m$ と $n$ が却 役複素数であれば $\lambda, \theta$ は実数であり，もし $m n=|m|^{2}$ $=|n|^{2} \leqq C^{2}$ したがって $\lambda \leqq 0$ すなわち严音速の条件 が満たされれば点 $u(m, n), v(m, n)$ は実数ホドグラフ 上にあることが分かる， $m, n$ が共役のときは(110)よ り $\xi, \eta$ あそうであるから， path $\xi(\mu), \eta(\nu)$ を共役に

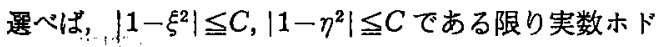
グラフ上でることが分かる． $\xi_{0}, \eta_{0}$ より発するての ような path を多数選ふことにより，その解の path で全亜音速ホドグラフを蔽うことができる，共役の initial paths 肪 sonic line 飞達すると $\lambda_{+}=\lambda_{-}$となり， 解は停止する。

次に超音速領域で解を求めるための path 考える. Initial characteristic $\eta=\eta_{0}$ 上で $\left|1-\xi^{2}\right|=C$ なる $\xi$ 点の軌跡を upper sonic locus と呼び, 同様に $\xi=\xi_{0}$

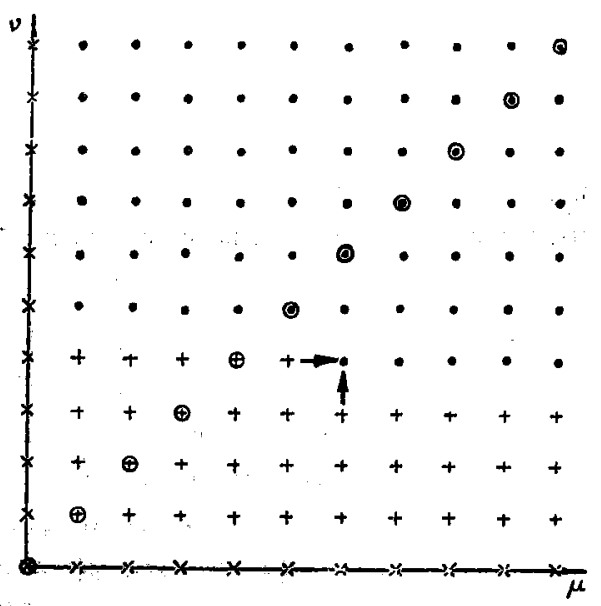

$x$ POIHTS ON THE INITIAL charactenistics POINTS ON THE GRID

- points at which the solution has been compUTED

- POINTS ON THE REAL HODOGRAPH PLANE

第 12 図 亜音速部分ての典型的 grid，各 initial charactéristic 上飞 11 点をとる. 矢印は次の計算点 (文献 23)
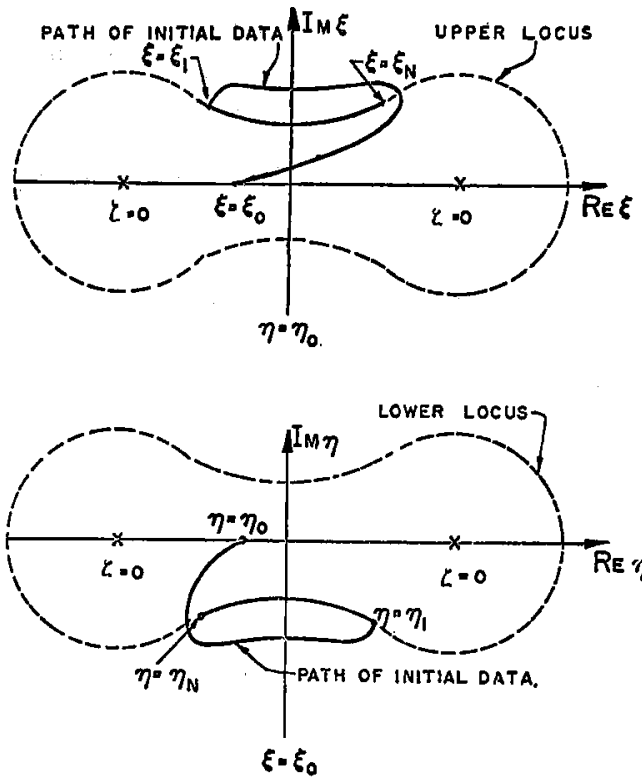

第 13 図 Initial characteristics $\eta=\eta_{0}$ (上図) $と \boldsymbol{\xi}=\boldsymbol{\xi}_{0}$ (下図) に沿う initial paths の典型. これらか 超音速頒域での解を生む. (文献 23)

上で $\left|1-\eta^{2}\right|=C$ となる $\eta$ 点の軌跡を lower sonic locus と呼ふ（第 13 図)．いま問題を離れて央数ホド グラフ平面での超音速の特性曲線法を考えてみよう。 すなわち $q, \theta$ は実数で, $a^{*} \leqq q \leqq q_{\max }$. このとき(108) 式の $\lambda$ は純虚数だから $|m|=|n|=C$ である。よ て超音速領域内の任意の点は, 上あに絶対值が $C$ で ある二つの characteristics $m, n$ の交点である. とて ろがこの $m, n$ に対応する $\xi, \eta$ は(110)式加分かる ように upper と lower の sonic locus 牦属している 一たとえば第 13 図の $\xi_{1}$ 之 $\eta_{1}$ (共役であってはいけな い).したがってそれぞれの出発点 $\xi_{0}$ と $\eta_{0}$ よりての $\xi_{1}, \eta_{1}$ に迳する両 path を選び，その上のすへての $\xi$, $\eta$ の組み合わ甘で $\lambda_{+} \neq \lambda_{-}$となるようにすれば，点 $\left(\xi_{1}, \eta_{1}\right)$ は超音速領域にある. さらに path $\xi_{0} \cdots \xi_{1}$ を upper locus 上で延長して点 $\xi_{2} \cdots \xi_{N}$ を加えれば，点 $\left(\xi_{2}, \eta_{1}\right), \cdots,\left(\xi_{N}, \eta_{1}\right)$ はやはり $\eta_{1}$-characteristic 上の 超音速点であろう． $\xi_{N} か ゙ ＼eta_{1}$ の共役点とすれば（ $\xi_{N}$ ， $\left.\eta_{1}\right)$ で sonic line に達し，解はこてで終結する，ふり 出しに戻って今度は path $\eta_{0} \cdots \eta_{1}$ を lower locus 上 $\eta_{2}$ まで延長し， $\eta_{2}$ について同様の過程をくり返し $\eta_{2}$-characteristic 上の超音速点 $\left(\xi_{2}, \eta_{2}\right) \cdots\left(\xi_{N}, \eta_{2}\right)$ 名得 られる. $\eta_{1}, \eta_{2} \cdots$ は $\xi_{1}$ の共役点 $\eta_{N}$ まで延長できる. かくして超音速領域で, sonic line と二本の characteristics $\xi_{1}, \eta_{1}$ とで区切られる籍围の解が，一対の initial path 上のデータから得られる(第 14 図). これ は real の特性曲線法で initial data が sonic line 上 で与えられた場合と同一の範囲である(第 14 四右上). 


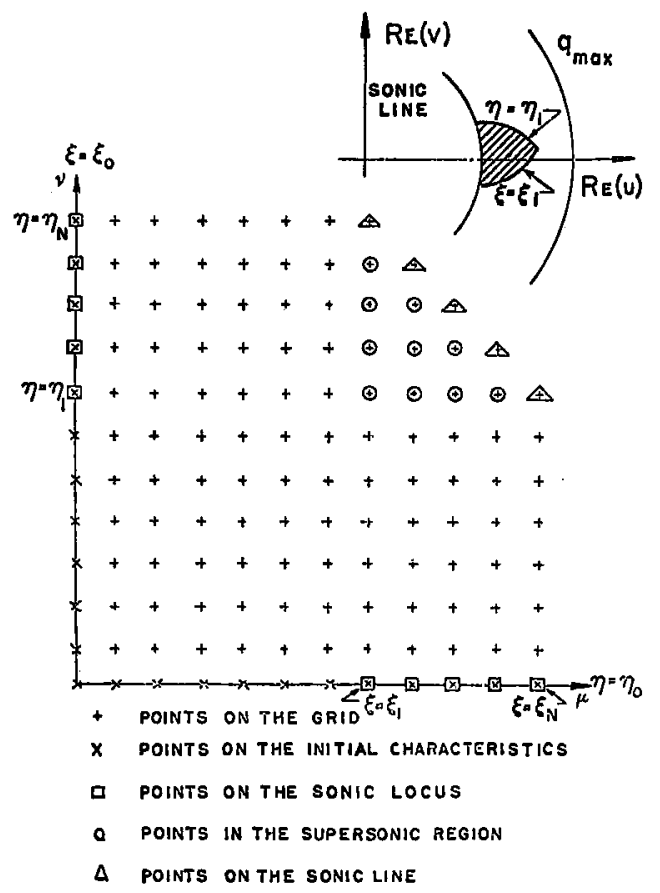

第 14 図第 13 図の initial paths に対応する grid を ע 面で示す. 右上はとの initial paths を用い て見出される実数ホドグラフ上の解の領域. (文献 23)

Regular solution まで求められると $x, y$ が $u, v$ の 関数として得られるから流れ関数 $\Psi=\left(1 / \rho_{0}\right) \int(\rho v d x$ - $\rho u d y)$ をやはり差分式に直して計算する. $q=0$ で $\Psi=0$ 上して内挿により $\Psi=0$ の軌跡を求め, 翼型形 状がきまる。

KORN はこの方法で対称翼型の 1 family を得た。 Initial characteristics は $\xi_{0}=\eta_{0}=$ 実数とし，その上で

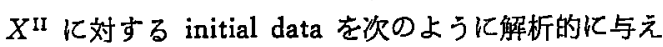
る.

$$
\left.\begin{array}{cc}
\xi=\xi_{0} \text { 上で } & H_{1}(\eta)=g\left(\xi_{0}, \eta\right)-\varepsilon_{0} \log \left(\alpha_{0}-\eta\right) \\
& -\varepsilon_{1} \log \left(\eta-\alpha_{1}\right) \\
\eta=\eta_{0} \text { 上て } & H_{2}(\xi)=g\left(\xi, \eta_{0}\right)-\varepsilon_{0} \log \left(\alpha_{0}-\eta_{0}\right) \\
& -\varepsilon_{1} \log \left(\eta_{0}-\alpha_{1}\right)
\end{array}\right\}
$$

こてに $g(\xi, \eta)$ は (106) の椅円柱の式で与える. した がって KORN の翼型も quasi-elliptical 翼の同類と考 えられよう. 特に $\varepsilon_{0}=\varepsilon_{1}=0$ の場合は， $M_{\infty} \rightarrow 0$ とす ると $\xi_{0}$ の值の選択にからわらず楕円柱まわりの非王 縮流汇近つく.

$\xi_{0}=0$ とすれば前後対称流となるが，計算上は $\xi_{0} \neq$ 0なるととが必要で前後非対称翼しか計算できない．

マッ八数が高まると limit line が翼内部から気流中に 首を出すが，その位置は $\xi_{0}$ が正なら翼の尾部，負な ら頭部である，翼表面の速度分布に変化をあたせるた め (120) 式の第二，第三項に見るように翼内に loga-

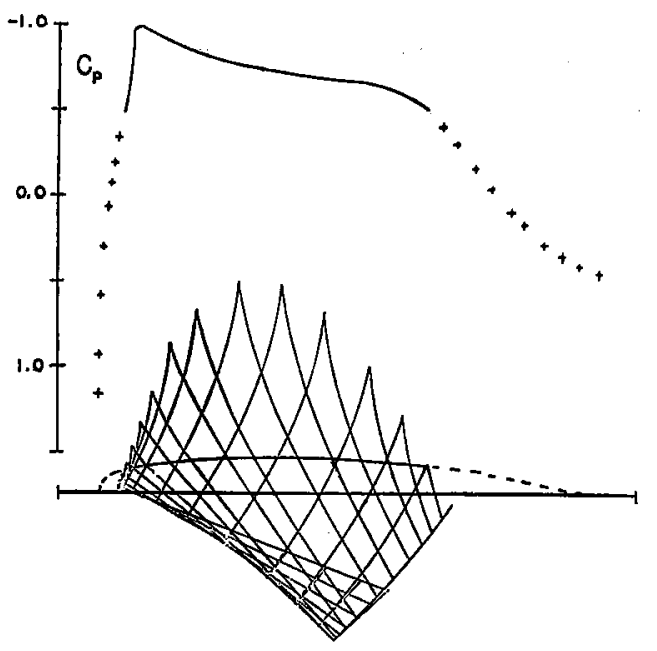

$M_{\infty}=.7906, \varepsilon=.15, \xi_{0}=-16, \varepsilon_{0}=.6, \alpha_{0}=.59$,

$\varepsilon_{1}=15, \quad \alpha_{1}=-1.50 . \quad M_{\text {max }}=1.2708, t / c=1372$.

第 15 図 KORN の対称翼の一例. (文献 23)

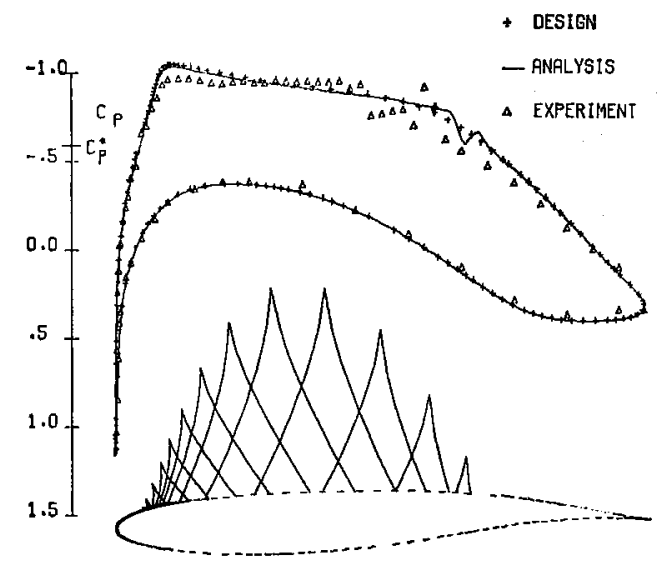

THEORY $M=.750 \quad c_{L}=.63 \quad C_{D}=.0003 \quad \alpha=0.00 \quad T / C=.418$ EXPERIMENT $M=.765 \quad c_{L}=.58 \quad c_{D}=.0110 \quad \alpha=.89 \quad R=21 \times 10^{6}$ 第 16 図 揚力をむつ KORN 翼（文献 26）

rithmic singularities を置いた，後縁近くにおく之後 縁付近の速度分布がゆるやかになったが，同時に頭部 の曲率を增し，ある場合注前縁を cusp にするととが 分かった，とれを補償するため前縁近くにもう一つの $\log$ 項をおいた，汃してパラメーターは $M_{\infty}, \xi_{0,}, \varepsilon$, $\varepsilon_{0}, \alpha_{0}, \varepsilon_{1}, \alpha_{1}$ の計 7 個である (すべて実数). 例を第 15 図に示す，流れはすべて対称であるから上半のみを描 いた。 対称軸より下の部分は翼内部への解の延長であ る，超音速領域では characteristics を描いてあり，そ の cusp するとてろをつなげば sonic line となる. 亜 音速部分の翼面は点線で描いてある. 計算時間は CDC 6600 を用いて翼型 1 收につき数分間と称している.

KORN は循環のある場合についても併行的に述へて 
いて，例えば(98)式はそのさい $\eta(\zeta)=\left(1-\zeta-b^{2}\right)^{1 / 2}+$ $i b(b$ は任意常数で円柱のときは $\Gamma / 4 \pi$ ととれば $z=$ $1 / \eta$ が澉密な式となる)，また（111）式は $z=Z^{\mathrm{l}} / \eta+$ $Z^{\mathrm{II}}+Z^{\mathrm{II}} \cdot \log \eta$ である，等々．本稿では詳細の発表さ れている揚力なしの場合に限ったが，揚力をあつ場合 も計算は成功した模様である ${ }^{26)}$ ．発表されている結果 を第 16 図に示す。

数值的ホドグラフ法としては別の構想がフランスの ONERA で試みられている(2),27) ととを付言する，揚 力のある場合を取扱い，ホドグラフ面でやはり解を singular, regular の両 solutions に分ける. Singular solution としては一様流に対応する点 $\tau=\tau_{1}$ で doublet と渦を表現するなるべく簡単な関数を与える ${ }^{62,28)}$ ，木 ドグラフ上任意に与えた $\Psi=0$ の曲線（翼の contour に対応) の上で singular solution の值を計算し，そ れの符号を変えたものを regular solution の境界值と する. Regular solutionは relaxation で解く、純亜 音速ならとの境界値問題は DIRICHLET の問題として well-posed であるが mixed flow のとき困難が伴う. また問題をやさしくするためホドグラフ上の有効流れ 領域に分枝点をるたない場合（分枝点は翼内部にあ る）を报っている．またての種の問題にお家芸の電気 的 analogy の応用む試みている ${ }^{299}$.

\section{9. 実医結果}

Shock-free mixed flow の翼型の実験結果をま之め て緑介しょう。ただしこてに挙げるのは理論的の厳密 解が得られているもの限った，したがっててれらは 必ずしあ実用に適する翼型ではない.

第 4 図の NIEUWLAND 対称翼に関してはSPEE \& UIJLENHOET $^{30}$ の実験結果が同時にプロットされて いる．計算結果はきわめてょく再現されており，てれ
を見れば誰しも essentially-isentropic compression の 事荚を疑わないであ万う．しかし細いことを言えば， 設計マッ八数よりいくらか高いところで理論值に最も 近い王力分布の得られていること，また分布自体に局 部的 disturbanceのあるととが認められる。てれらは ここで紹介するどの実験にも共通のととがらである. あちろん実験では模型の裂作誤差の外に境界層の影

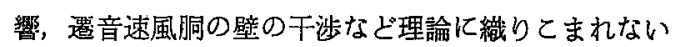
要索の入ることは考虑しなりればならない．この実験 はレイノルズ数（翼拡長基準） $2 \sim 2.5 \times 10^{6}$ 程度であ るが，12\% 翼弦のところで自由還移を行ない，また peak 後の圧力上昇部に剥離の小 bubble があるとの ことである，第 17 図はそのうちの一つの翼について， off-design 状態での王力分布を示す. 設計点 (理論値 と最むよく一致する点) を外机ると，たとえばマッハ 数がより高くても低くてあ，より顕著な衙撃波の現わ れることが分かる。これは mixed-flow の厳密解が孤 立解であるととに対芯するものであろう．しかし設計 点を僅か外れてあ抵抗增加はそれ程大きくほいことが 示されている.

NLR の揚力をもつ翼については, BOERSTOEL ら22) の簡単な記述中に一つの翼の実験結果が示されてい る. 第 9 図(c)がそれで，対称翼ほど計算結果との一 致がよくない．これは対称翼でも生じる上記の実験的 制約の外に，掦力をもつ翼の場合は境界層の影響等に より揚力係数がおち机ばそれが直ちに前縁湍み点の位 㯰に関係し，そのため翼上下面の flow pattern がく ずれるためであるう，事実この実験では理論より $20 \%$ あ低い揚力係数しか得られなかった模様である。その 外，自然遷移之強制選移とで peak およびその直後で の分布がかなり異なることが認められる。自然瑮移で は前縁より 18〜25\% 翼弦の位置隹離 bubble のあ ることが報じられている。

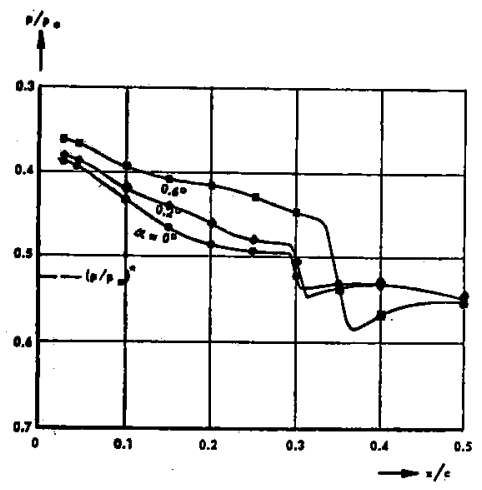

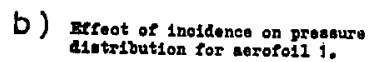
a) The effect of Nach nuaber on presurse
distribution for eorofoli 1 .

第 17 圀第 4 四の Aerofoil 1 に対する off-design 性能.（文献 30) 
航技研の翼型については，第 10 図 a) 中に $2 \mathrm{~m}$ 遷 音速風胴で害験した結果. ${ }^{31}$ をプロットした。この例で は前縁 peak はあまり強くなく， limit line の出現ま でにはまだマッハ数に余裕がある，理諭值とかなりよ く合っているが，理論值よりやや高めのマッハ数， やや大きい迎角で最良の一致が得られているととは BOERSTOEL らのあのと共通の傾向である．その理由 はやはり粘性の影響などによる揚力の低下，またそれ に基く前縁湟み点の移動にあると思われる，図に示す 最す理論值に近い分布は，渐み点位置をほぼ理論值に 合わせて得られたすのである。しかしマッハ数，迎角 が理諭とおりでないため結果的には peak が強すぎ また超音速領域の下流端で過王縮の現われているのが 注目される。

KORN翼の揚力をもつ場合について最近カナダNAE の 60 in $\times 15$ in 二次元風胴で実験された結果が第 16 図中にプロットされている。これも理論王力分布に最 あよく合ったデータを示したあので，それが設計点を やや上まわるマッ八数，迎角で得られていることは他 の翼型と同様である，やはり下面の合致はよいが上面 に若干の disturbance が認められる。この結果では上 面の peak が理論値より低く現われている，後縁付近 の分布は理論值をきわめてよく再現しているが，これ は後縁付近の厚みが少ないこと，試験レイ/ルズ数が きわめて高いととに基つくすのであろう.

NIEUWLAND に先立って棈円柱まわりの流れを基と する厳密解を LEVEY が求めたことはさきに述へたが, quasi-elliptical 翼の成功に刺激されて LEVEY 翼の再 試験を最近 SECOMB $^{32)}$ が行なった。 その結果を第 18 図に紹介する，てれは前後縁とも cusp の（上下）対 称翼で，形状，速度分布之あ友近・玉田の翼 ${ }^{33)}$ (ホド グラフ法の近似解法により求められたもの）に似てい
る。罒に見るように翼弦の中央部に超音域領域があ り，50\% 翼弦をこえた後でやや急激に亜音速へと再 压縮される，理論と実験との一致は必ずしもよくない が，この圧縮もほほ等エントロピー的と見てよいので はないであろうか，前縁が cuspであるから LEVEY 翼 は奏用的に興味の少ないあのであるが，非 peaky 翼 の一例としてその実験的栝証は與味がある.

\section{0. むすび}

前節に述ぺた実験結果により（それに厳密解によら ない多数翼型の実験結果をも加えて)，PEARCEY の peaky 翼提唱以前に支配的であった shock-free flow に対する偏見はふっしょくされたと考えてよいであろ う. Shock-free flow に対する過去の否定論が根拠と したのは，よく知られているように次の諸点にある.

i ）たとえ翼のまわりに isentropic mixed flow が理 論的にあったとしてすそれは孤立解であるから寒現は 困難であろう．超音速領域に接する物体形状に局部的 微小変化があれば isentropic flow としての隣接解が ないから shock-free flow はけしとんでしまうであろ うとの数学的議論, また ii）超音速領域の下流に生じ る小掜乱は超音速領域を通りぬけて上流に伝播できな いから，時間がたつにつれて超音速領域末端で蒛皘 し，衝撃波を構成せずにはすまない，等々である。乙 のうち i ) については数学的には正にそのとおりかす 知れない. しかし自然現象の常として shock-free flow に隣接して強い shock を伴う流れが必ずあるとは考 えられず，あしその近傍にほとんど shock-free であ る流れのかなりの領域が存在すれば実用上はまず問題 がない．また ii ）についてあ一次元の管内の流れとは 異なり，二次元の翼まわりの流れでは掜乱の蓄皘され ない例が (peaky 翼については) 実験的, 理論的 ${ }^{34}$ に

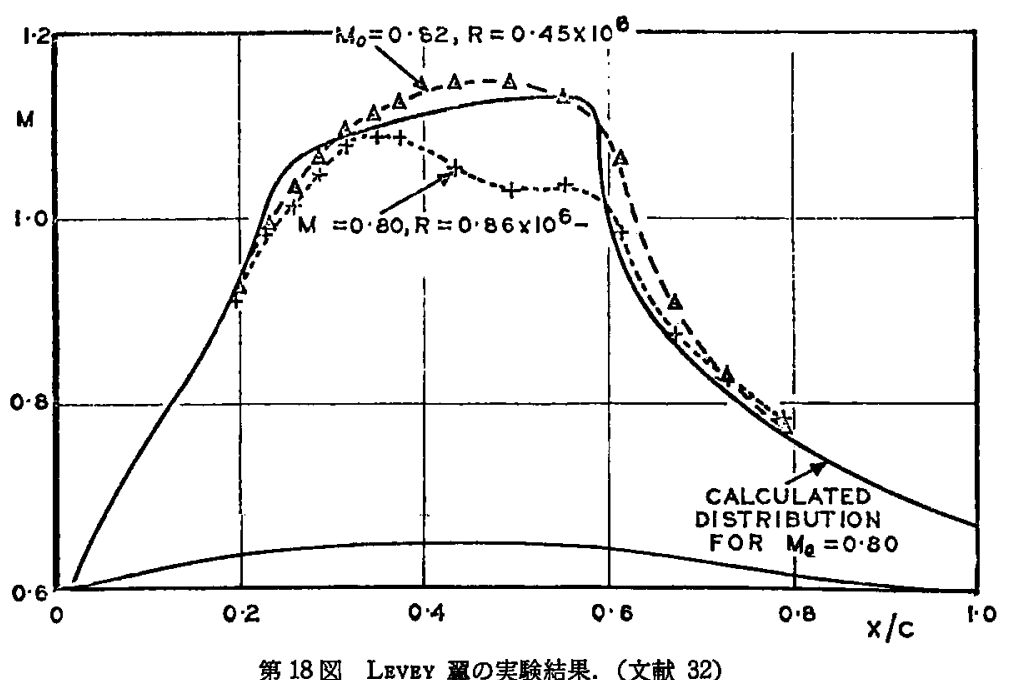


奏証されようとしている(これらの反論てついてはた とえば文献 35 参照).

本稿で述へた厳密解による shock-free 翼型は，何 といってあまだ種類が少なく，またある実際的の意図 をもって設計されたというより，いわば数学上の便宜 に合わせて構成されたものであるてとは否定できな い. 古典翼理論の歴史上に類似を求めれば，やっとジ ューコフスキー翼が得られたぐらいのところであろう か. あっと family をふやして shock-free 翼型の可 能性の範团を探究することは有意義であろう。また shock-free 翼型が peaky 型のものに限るかとの疑問 に確信ある解答を与えるにはもう少しデータが必要で あろう。

遷音速翼型の性能の良否をさめるのは衝撃波の関連 ばかりでなく，もちろん粘性阅関係する数多くの要素 に支配されるし，実用翼型としては低速性能との妥協 あ必要であろう。これらは今後実験データの皘重ねに よって解明される問題であり，翼型研究の次の段階の 仕事は主としてての分野で展開するのではあるまい 加.

最後に“直接問題”に関する最近の成果を一，二紹 介する，直接問題では翼型形状をあらかじめ与えるか ら isentropic mixed flow の得られる保証はなく, 流 れを解くさいには衙撃波の出現を覚悟し，その用意が なければならない，そのため人工的粘性の導入など数 值計算上の技術が開発されている. 直接問題のうち, 非定常運動方程式を時間を追って数値的に解き，その 極限として定常解を求める方法は MAGNUS \& YosHIHARA $^{36)}$ を始め多くの人が試み，かなりの成果を得て いる. LAX \& WENDROFF 法の応用が主体で，てれら は流体力学の基碐式を電子計算戌の助けを借りて解て うとする一つの流れに属すると見て上かるう。これら については里潹 ${ }^{37}$ の展望に詳述されている.

最近，王縮流の定常方程式を物理面で，あるいは便 利な面に変換した上で relaxation で解く方法が予想外 の進展を見甘ている，Relaxation 途上で， grid 上の 各点で速度を計算して亜音速か超音速かを判断し，伩 円型と双曲型とにそれぞれ適した差分のとり方を使い

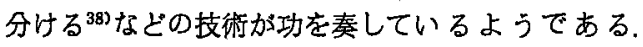
MURMAN \& COLE ${ }^{38)}$ および KRUPP \& MURMAN ${ }^{399}$ は 要音速小じょう乱方程式を差分化して，前者は揚力を むたない翼型の場合を，後者は掦力をむつ翼型と斬対 称物体を取り报い，いくつかの例を計算している. STEGER \& LOMAX ${ }^{40)}$ は压縮流の完備した式（小じょ う乱でなく）を適当な座標に変換した上で同様の計算 を揚力あり，なしの場合につき行なっている，さらに GARABEDIAN \& $\mathrm{KORN}^{26)}$ は, 純亜音速の翼型解析に
広〈利用される SELLS ${ }^{41)} の$ 方法（微分方程式の座標 を変换して翼のまわりの流れを巣位円一物理面無限遠 点がその中心となるよう一の内部領域に写像する）上 MURMAN \& COLE の差分方式とを組み合わせる方法 を編み出し，KORN の揚力をあつ翼型の一つにつき設 計点呫よび設計点外での圧力分布を求め，KORN の理 論および実跧と比較し良好な結果を示しているのが师 象的である. 第 16 図に analysis と注記してある曲線 がそれである.（ここに示したのは設計点での計算.)

最後に面積法則の創案者であるWHITCOMB が “supercritical wing”なる名称で塎音速翼を開発し，飛行 試験を行なっているとの報道があるが，詳細不明で紹 介できないのが残念である，噂によれば第 16 図の KORN 翼型に似た形状とのととである ${ }^{26)}$.

本講座を書くにあたり最新の文献を提供して下さっ た佐藤淳造氏に厚く感謝の意を表する。

\section{付 録}

\section{【I 基礎方程式の誘道}

連続の式: $\left(\rho u / \rho_{0}\right)_{x}+\left(\rho v / \rho_{0}\right)_{y}=0$

および渦なしの条件

$$
v_{x}-u_{v}=0
$$

から次式で定義される速度ポテンシャル $\Psi$ を導く

$$
\Phi_{x}=u, \Phi_{y}=v ; \Psi_{x}=-\rho v / \rho_{0}, \Psi_{y}=\rho u / \rho_{0}
$$

ただし $\rho_{0}$ は常数，ここでは激み点の密度をとる（A． 3)より,

$$
\begin{aligned}
& d \Phi+i\left(\rho_{0} / \rho\right) d \Psi=(u d x+v d y) \\
& \quad+i(-v d x+u d y)=(u-i v)(d x+i d y) \\
& \quad=q e^{-i \theta} d z \quad(\mathrm{~A} \cdot 4)
\end{aligned}
$$

よって $q, \theta$ を独立変数とすると

$$
\begin{aligned}
& \partial z / \partial q=\left(e^{i \theta} / q\right)\left[\Phi_{q}+i\left(\rho_{0} / \rho\right) \Psi_{q}\right] \\
& \partial z / \partial \theta=\left(e^{i \theta} / q\right)\left[\Phi_{\theta}+i\left(\rho_{0} / \rho\right) \Psi_{\theta}\right]
\end{aligned}
$$

これより $\partial^{2} z / \partial q \partial \theta=\partial^{2} z / \partial \theta \partial q$ の関係は次のようにな る.

$$
\begin{aligned}
& i\left(e^{i \theta} / q\right)\left[\Phi_{q}+i\left(\rho_{0} / \rho\right) \Psi_{q}\right] \\
& \quad=-\left(e^{i \theta} / q^{2}\right) \Phi_{\theta}+i e^{i \theta}\left[d\left(\rho_{0} / \rho q\right) d q\right] \Psi_{\theta}
\end{aligned}
$$

この実数部と虚数部をとればホドグラフ式:

$$
\Phi_{q}=q\left[d\left(\rho_{0} / \rho q\right) / d q\right] \Psi_{\theta}, \quad \Phi_{\theta}=\left(\rho_{0} q / \rho\right) \Psi_{q}
$$

を得る。

断熱法則 $p=k \rho^{r}$ ( $k$ は常数) を仗定すれば BERNOULLI の式は

$$
\begin{gathered}
q^{2} / 2+\int d p / \rho \quad\left(=q^{2} / 2+\{k \gamma /(\gamma-1)\} \rho^{\gamma-1}\right) \\
=\text { const }=q_{\mathrm{max}} / 2 \quad(\mathrm{~A} \cdot 7)
\end{gathered}
$$

$q=0$ のとき $\rho=\rho_{0}$ で, $\{k \gamma /(\gamma-1)\} \rho_{0}^{\gamma-1}=q_{\max }^{2} / 2$ 
これと(A·7)より， $\tau=q^{2} / q_{\max }{ }^{2}$ を用いて

$$
\rho / \rho_{0}=(1-\tau)^{1 /(\tau-1)}
$$

これを(A.6)に入れ， $q$ をすべて $\tau$ に変えれば

$P(\tau) \cdot \partial \Phi / \partial \tau=\partial \Psi / \partial \theta$

$Q(\tau) \partial \Psi / \partial \tau=\partial \Phi / \partial \theta$

$P(\tau)=\frac{2(\gamma-1) \tau}{(\gamma+1) \tau-(\gamma-1)}(1-\tau)^{\gamma /(\gamma-1)}$

$Q(\tau)=\frac{2 \tau}{(1-\tau)^{1 /(r-1)}}$

(A.9)

が得られる。てれらより Фを消去して本文 ( 3 ) 式を 得る。

また別途(A-7)より， $d p / d \rho=a^{2}$ (局部音速) として， $q d q+d p / \rho=u d u+v d v+\left(a^{2} / \rho\right) d \rho=0$

$(A \cdot 10)$

てれと $(\mathrm{A} \cdot 1)$ より $\rho$ を消去して

$$
\left(a^{2}-u^{2}\right) u_{x}-u v\left(u_{y}+v_{x}\right)+\left(a^{2}-v^{2}\right) v_{y}=0
$$

これと渦なしの条件 (A.2) とを

$$
\left.\begin{array}{c}
u_{x}=j y_{v}, u_{y}=-j x_{v}, v_{x}=-j y_{y}, v_{y}=j x_{u} ; \\
j=u_{x} v_{y}-u_{y} v_{x} \text { (Jacobian) }
\end{array}\right\}
$$

により変換すれば本文 $(92,93)$ 式となる.

また本文 7. までの理論では流れ関数を木ドグラフ 面で求めるととに終始するが，そのあ之物理面で物体 形状 ( $\Psi=0$ の軌跡), また必要なら流線形状を求める ととが残っている. その変換には $(A \cdot 4)$ を用いる，具 体的には(A.6)を用いて(A.5)上り $\Phi$ を消去し， $q$ を $\tau$ に直した次式を用いる：

$$
\left.\begin{array}{rl}
z_{\theta} & =\left(\frac{\tau_{1}}{\tau}\right)^{1 / 2} \cdot \frac{2 \tau}{(1-\tau)^{1 /(\gamma-1)}} \cdot e^{i \theta}\left(\Psi_{\tau}+\frac{i}{2 \tau} \Psi_{\theta}\right) \\
z_{\tau} & =\left(\frac{\tau_{1}}{\tau}\right)^{1 / 2} \frac{2 \tau}{(1-\tau)^{1 /(\tau-1)}} \\
& \times e^{\prime \theta}\left(\frac{i}{2 \tau} \Psi_{\tau}-\frac{1-(\gamma+1) \cdot \tau /(\gamma-1)}{4 \tau^{2}(1-\tau)} \Psi_{\theta}\right)
\end{array}\right\}
$$

(ただし $\left.\tau_{1}=1 / q_{\max }{ }^{2}\right)$. 上式より $z$ が計算できるが， それは $\Psi$ の計算に劣らず手数のかかる仕事である.

\section{(II) 微分方程式の変換}

上記微分方程式(A.6) より出発して，独立変数のう $5 q$ の代わりに別の尺度を用いて方程式を変換しいく らか整った形にすることができ，解の性質を調べると きに利用される， $\lambda=\lambda(q)$ を新しい変数とすると（A. 6) は

$$
\begin{aligned}
& \lambda^{\prime}(q) \Phi_{\lambda}=q\left[d\left(\rho_{0} / \rho q\right) / d q\right] \Psi_{\theta} \\
& \Phi_{\theta}=\left(\rho_{0} q / \rho\right) \lambda^{\prime}(q) \Psi_{\lambda}
\end{aligned}
$$

BERNOULLI の式(A.10)を用いて $q\left[d\left(\rho_{0} / \rho q\right) / d q\right]$ を $-\left(\rho_{0} / \rho q\right)\left(1-M^{2}\right)$ と書き $(M=q / a), 1-M^{2}>0$ (純 亚音速)のとき

$$
\lambda^{\prime}(q)=\sqrt{1-M^{2}} / q,
$$

すなわち $\lambda(q)=-\int_{q}^{a} \sqrt{1-M^{2}} \cdot d q / q$

と置く（積分の上端には音速 $a$ を選ぶ）すると（A. 14) は

$$
\Phi_{\lambda}=-\lambda^{\prime}(q)\left(q \rho_{0} / \rho\right) \Psi_{\theta}, \quad \Phi_{\theta}=\lambda^{\prime}(q)\left(q \rho_{0} / \rho\right) \Psi_{\lambda}
$$

さらに

$$
\lambda^{\prime}(q)\left(q \rho_{0} / \rho\right)\left(=\sqrt{1-M^{2}} \rho_{0} / \rho\right)=1 /[V(\lambda)]^{2}
$$

と置けば

$$
\begin{aligned}
V & =\left[(1-\tau)^{1 / \tau_{*}} /\left(1-\tau / \tau_{*}\right)\right]^{1 / 4} \\
& =[-P(\tau) / Q(\tau)]^{1 / 4}
\end{aligned}
$$

と表わされる $\left(\tau_{*}=(\gamma-1) /(\gamma+1)\right.$ で音速の之きの 值)。すると $(\mathrm{A} \cdot 17)$ は

$$
-[V(\lambda)]^{2} \cdot \Phi_{\lambda}=\Psi_{\theta}, \quad[V(\lambda)]^{2} \Phi_{\theta}=\Psi_{\lambda}
$$

てれからゅを消去すれば

$$
\Psi_{\lambda \lambda}+\Psi_{\theta \theta}=T \Psi_{\lambda}
$$

ここに

$$
\begin{aligned}
T & =2 V^{\prime} / V=-\left\{d / d \lambda \cdot\left(\rho_{0} \sqrt{1-M^{2}} / \rho\right)\right\} \\
& \div\left(\rho_{0} V \overline{1-M^{2}} / \rho\right)
\end{aligned}
$$

さらに従㾖变数 $\Psi$ あ，次の $\Psi^{0}$ 亿置換える.

$$
\Psi(\lambda, \theta)=V(\lambda) \cdot \Psi^{0}(\lambda, \theta)
$$

すると $(\mathrm{A} \cdot 21)$ は

$$
\Psi^{0}{ }_{\lambda \lambda}+\Psi_{\theta \theta}^{0}+F(\lambda) \cdot \Psi^{0}=0
$$

となる.とてに

$$
F(\lambda)=-\frac{d^{2}}{d \lambda^{2}}\left(\frac{1}{V(\lambda)}\right) /\left(\frac{1}{V(\lambda)}\right)=\frac{V^{\prime \prime}}{V}-\frac{2 V^{\prime 2}}{V^{2}}
$$

(A.21)，(A.24)のように方程式が簡単化されたの は変数 $\lambda$ の採用による. (A.15) で定義された $\lambda$ をて で表わすと，

$$
\begin{aligned}
\lambda(= & \left.-\int_{q}^{a} \frac{\sqrt{1-M^{2}}}{q} d q\right)=\tau_{*}^{-1 / 2} \tanh ^{-1} \sqrt{\frac{\tau_{*}-\tau}{1-\tau}} \\
& -\tanh ^{-1} \sqrt{\frac{1-\tau / \tau_{*}}{1-\tau}}
\end{aligned}
$$

となる. $\lambda$ の值は $q=0$ で $-\infty, q=a_{*}$ (音速) で 0 ; 超音速では虚数となり通常使われない．

しかし超音速，すなわち $\lambda$ を虚数にまで搪張して $\lambda=i \Lambda$ ( $\Lambda$ : 実数) とすれば， $\Lambda$ は PRANDTL-MEYER 関数 4 23

$$
\Lambda=\int_{a}^{q} V \overline{M^{2}-1} \cdot d q / q
$$

である. $\Lambda$ を用いるとたとえば(A·21)は $\Psi_{\Lambda A-\Psi_{\theta \theta}}$ $=T_{1}(\Lambda) \Psi_{\Lambda}$ の形となり，乙れは双曲型の微分方程式 
ぞ,

$$
d \Lambda \pm d \theta=0
$$

なるcharacteristicsをもつ。

さて，亜音速の入に戻り，物体まわりの流れを取り 报うさいはてれに常数 $\sigma$ を加え，

$$
s=\lambda+\sigma
$$

を変数とする方が便利である。ことに

$$
\begin{array}{cc}
\sigma= & -\{(\gamma+1) /(\gamma-1)\}^{1 / 2} \tanh ^{-1}\{(\gamma-1) /(\gamma+1)\}^{1 / 2} \\
& +(1 / 2) \log \{2(\gamma-1)\}
\end{array}
$$

と表わされるあので，とれにより $\tau \rightarrow 0\left(q_{\max } \rightarrow \infty\right)$ で

$$
\lim _{\tau \rightarrow 0} e^{2 s} / \tau=1
$$

すなわちての小さいとき $s \approx \log \left(q / q_{\mathrm{max}}\right)$ なる性質をあ たせることができる. $\sigma$ 仿常数だから(A-21)，(A-24) の敞分方程式は変数 $\lambda$ を $s$ 書直しても同型である.

(A.24)から，例えば次のようなととが導き出せる. $\Psi^{0}=\psi_{v^{0}} \cdot e^{i v \theta}$ と置いて变数分離すると,

$$
\left(d^{2} / d s^{2}\right) \phi_{\nu}{ }^{0}-\nu^{2} \psi_{\nu}{ }^{0}+F(s) \psi_{\nu}{ }^{0}=0
$$

これより $|\nu|$ の大きいとき $\phi_{\nabla}^{0} \sim e^{\nu s}$, したがって

$$
\psi_{\text {, }}\left(\equiv \nabla \phi_{\nu}{ }^{0}\right) \sim V \cdot e^{\nu s}
$$

であることが直感的に分かる（ただし要音速に限る）.

\section{[III] Chaplygim の特解}

本文 2. に述べたように微分方程式 (3)の特解は

$$
\phi_{\nu}(\tau) e^{ \pm i \nu \theta}
$$

ただし $\left.\phi_{\nu}(\tau)=\tau^{1 / 2} \cdot F\left(a_{\nu}, b_{\nu} ; \nu+1 ; \tau\right)\right\}$

である.ここに $a_{n}, b$, は次式よりきめられる.

$$
\begin{aligned}
& a_{\nu}+b_{\nu}=\nu-1 /(\gamma-1) \\
& a_{\nu} b_{\nu}=-\nu(\nu+1) / 2(\gamma-1)
\end{aligned}
$$

(3)式の変数分離によって得られる常微分方程式 :

$$
\begin{gathered}
\tau(1-\tau) \frac{d^{2} f}{d \tau^{2}}+\left(1+\frac{2-\gamma}{\gamma+1} \tau\right) \frac{d f}{d \tau} \\
-\nu^{2}\left\{1-\frac{r+1}{r-1} \tau\right\} \cdot \frac{1}{4 \tau} f=0
\end{gathered}
$$

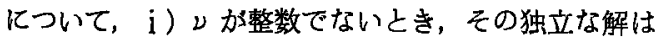
$\phi_{\nu}(\tau)$ と $\phi_{-\nu}(\tau)$ である.

ii ） $\nu=2,3, \cdots, \nu, \cdots$ のとき，独立な解は一つは $\phi_{n}(\tau)$, 一つは CHAPLYGIN の第二種関数（次式で表わ される) である :

$$
\phi_{n}^{*}(\tau)=\lim _{\nu \rightarrow-n} \partial / \partial \nu\left[(\nu+n) \phi_{\nu}(\tau)\right]
$$

iii） $\nu= \pm 1$ のとき解は closed form で書ける:

$$
\begin{aligned}
& \phi_{1}=[(\gamma-1) / r) \tau^{-1 / 2}\left\{1-(1-\tau)^{r /(\gamma-1)}\right\} \\
& \phi_{-1}=\tau^{1 / 2}+\phi_{1} / 2(\gamma-1)
\end{aligned}
$$

iv） $\nu=0$ のときの解は， $\psi_{0}=1$ と

$$
\left\{(\partial / \partial \nu) \phi_{\nu}(\tau)\right]_{\nu=0}=\int_{0}^{\tau}\left\{(1-\tau)^{1 /\left(\gamma_{7}-1\right)} / 2 \tau\right\} d \tau
$$

(A.33) 式中の超幾何関数を級数展開して次のこ之 が分かる:すなわち $\phi_{\nu}(\tau)$ は，複素変数 $\nu$ の関数之 見ると， $\nu=-2,-3, \cdots,-n, \cdots$ で単純な極をもち， そこでの留数は

$$
\lim _{\nu \rightarrow-n}\left[(\nu+n) \psi_{\nu}(\tau)\right]=-n C_{n} \psi_{n}(\tau)
$$

こと

$$
C_{n}=\frac{\left(a_{n}-1\right) !\left(n-b_{n}\right) !}{\left(a_{n}-n-1\right) !\left(-b_{n}\right) !(n !)^{2}}
$$

これらは頻繁に用いられる。

\section{(IV) $e_{k}$-transform}

収束のおそい級数を早いむのに変換する $e_{k}$-transform D威力については SHANKS ${ }^{16)}$ の示した例が印象 的である. いま $\tan ^{-1} 1=\pi / 4$ なるこよより $\tan ^{-1} x$ の 級数展開式を利用して $\pi$ を計算しようとする.すなわ 5 LEIBNITZ の級数: $\pi=4-(4 / 3)+(4 / 5)-(4 / 7)+\cdots$. この右辺はすこぶる取束が怙そく，“美しいが実用上 役に立たない”級数である．10 項までの和をとってす $\pi \approx 3.0418 \cdots$, すなわち一桁の精度しかない. 8 桁の 精度で $\pi$ を求めるには，信じ難いことであるが，約 40,000,000 項の和が必要となる，ところでその最初 の 10 項の值を知り $e_{k}$-transform を適用すれば, $\pi \approx$ 3. 1415927 すなわち 8 桁の精度が得られるのである.

$$
\text { 文献 }
$$

1）佐藤淳造：Peaky 翼型について. 日本航空宇宙学会 誌, 18 巻, 201 号, pp. 374-388 (1970/10).

2) Pearcey, H. H. : The Aerodynamic Design of Section Shapes for Swept Wings. Advances Aero. Sci., Vol. 3 (1962), Proc. 2 nd. Internat. Congr. Aero. Sci., pp. 277-322.

3) HAY, J. A. : Vickers V. C. 10. Part 1-Aerodynamic Design. Aircraft Engg. Vol. 34, pp. 158-164(1962).

4) Hawker Siddeley Trident, Aerodynamic Design and Flying Controls. Aircraft Engg. Vol. 36, pp. 172-181 (1964).

5) Pearcey, H. H. \& Osborne, J. : Some Problems and Features of Transonic Aerodynamics. ICAS Paper, No. 70-14 (1970).

6) Legendre, R. : Calcul d'un Profil d'Aile Subsonique ou Transsonique. Recherche Aéro., No. 126 pp. 3-13 (1968).

7) Chaplygin, S. A. : On Gas Jets. Sci. Memo. Moscow Univ. Math. Phys. No. 21 (1904). Transl. NACA TM 1063 (1944).

8) Lighthil., M. J. : The Hodograph Transformation in Transonic Flow. II. Auxiliary Theorems on the Hypergeometric Functions. III. Flow Round a Body. Proc. Roy. Soc. London, A 191, pp. 341 -369 (1947).

9) Cherry, T.M. : Flow of a Compressible Flow About a Cylinder. Proc. Roy. Soc. London, A 192, pp. 45-79 (1947).

10) Goldstein, S., Lughthill, M. J., \& Craggs, J.W. : On the Hodograph Transformation for HighSpeed Flow. I. A Flow Without Circulation. Quart. Jour. Mech. \& Appl. Math. Vol. 1, pp. 
344-357 (1948).

11) Cherry, T.M. : Numerical Solutions for Transonic Flow. Proc. Roy. Soc. London, A 196, pp. 3236 (1949).

12) Morawetz, C.S.: On the Non-Existence of Continuous Transonic Flows Past Profiles, I III. Comm. Pure Appl. Math., Vol. 9, pp. 45-68(1956); Vol. 10, pp. 117-131 (1957); \& Vol. 11, pp. 129144 (1958): Morawetz, C.S. : Non-Existence of Transonic Flow Past a Profile. Comm. Pure Appl. Math., Vol. 17, pp. 357-369 (1964).

13) Nieuwland, G.Y.: The Computation by Lighthill's Method of Transonic Potential Flow Around a Family of Quasi-Elliptical Aerofoils. NLR-TR T. 83 (1964).

14) Bozrstoel, J. W. A Survey of Symmetrical Transonic Potential Flows Around Quasi-Elliptical Aerofoil Sections. NLR-TR T. 136 (1967).

15) Levey, H.C. : High Speed Flow of Gas Past an Approximately Elliptic Cylinder. Proc. Cambr. Phil. Soc., Vol. 46, pp. 479-491 (1950). また A Shock-Free Airfoil. Jour. Aero. Sci. Vol. 23, No. 12. pp. 1129-1130 (1956).

16) Shanks, D: Non-Linear Transformations of Divergent and Slowly Convergent Sequences. J. Math. Phys., Vol. 34, pp. 1-42 (1955).

17) Wyns, P.: The Rational Approximation of Functions Which Are Formally Defined by a Power Series Expansion. Math. Comp., Vol. 14, No. 70, pp. 147-186 (1960).

18) Lighthill, M. J.: On the Hodograph Transformation for High Speed Flow. II. A Flow with Circulation. Quart. J. Mech. Appl. Math., Vol. 1, pp. 442-450 (1948).

19) Cherry, T.M.: Flow of a Compressible Fluid About a Cylinder, II. Flow with Circulation. Proc. Roy. Soc. London, A. 196, pp. 1-31 (1949).

20) Nieuwland, G.Y.: Transonic Potential Flow Around a Family of Quasi-Elliptical Aerofoil Sections. NLR-TR T. 172 (1967).

21) Borrstozl, J. W. \& Uijlenhoet, R. : Lifting Aerofoils with Supercritical Shock-Free Flow. NLRMP 70015 U (1970).

22）高梨進：揚力をあつ翼型まわりの䙴音速連続流の一解 法，航技研報告近刊.

23) KorN, D. G.: Computation of Shock-Free Transonic Flows for Airfoil Design. Courant Inst. of Math. Sci., New York Univ. Rep. NYO-1480-125 (1969).

24) Garabedian, P. R. \& Lieberstein, H. M.: On the Numerical Calculation of Detached Bow Shock Waves in Hypersonic Flow. J. Aero. Sci., Vol. 25, pp. 109-118 (1958).

25)たとえば Fonsythe, G.E. \& Wasow, W. R. : Finite Difference Methods for Partial Differential Equations. John Wiley \& Sons. (1960).

26) Kacprzynski, J. J., Ohman, L. H., Garabedian, P. R., \& KorN, D.G. : Analysis of the Flow Past a Shockless Lifting Airfoil in Design- and Off-Design Conditions. Nat. Res. Council of Canada,
Aero. Rep. LR-554 (Nov. 1971).

27) Bevierre, P. : Calcul Numérique de Profil d'Ailes Subcritiques par la Méthode de l'Hodographe. AGARD C.P. 35, pp. 8-1 8-11 (1968).

28) Legendre, R.: Singularité de l'Hodographe de l'Écoulement Plan Réversible d'un Fluide Com pressible autour d'un Profil Portant. C. R. Acad. Sci. Paris, t. 266, Série A, pp. 250-253(1968/1/22).

29) Rigaut, F: Détermination Analogique de Profil d'Aile en Régime Transsonique. AGARD C.P. 35 , pp. 7-1 7-20, (1968).

30) Spez, B. M. \& Uijlenhoet, R: Experimental Verification of Shock-Free Transonic Flow Around Quasi-Elliptical Aerofoil Sections. NLR-MP 68003 $\mathrm{U}$, (1968).

31）重見孝，竹内理，高梨進，鈴木弘一，中村正剛: 遷音 速流䇴密解により設計された衝撃波のない，揚力をす つ翼型の風胴試験. 航技研熕料近刊.

32) Sесомв, D. A. : A wind Tunnel Investigation of Levey's Shock-Free Aerofoil. Note Aero. 325, Aero. Res. Lab. Australia, (1970).

33) Tomotika, S. \& Tamada, K.: Studies on TwoDimensional Transonic Flows of Compressible Fluids, III. Quart. Appl. Math. 9, pp. 129-147 (1951).

34) SpeE, B. M. : Wave Propergation in Transonic Flow Past Two-Dimensional Aerofoils. NLR TN 123 (1966): SPEE, B. M. : Investigations on the Transonic Flow Around Aerofoils. NLR TR 69122 $\mathrm{U}$, (1969).

35) Nreuwland, G. Y. \& SpeE, B. M. : Transonic ShockFree Flow, Fact or Fiction? NLR-MP 68004 U (1968).

36) Magnus, R., Gallaher, W., \& Yoshihara, H.: Inviscid Supercritical Airfoil Theory. AGARD C. P. 35, pp. 3-1 3-5(1968); また MAGNus, R., \& Yoshumara, H.: Inviscid Transonic Flow over Airfoils. AIAA Paper No. 70-47 (1970).

37) 里深信行：压缩性流体力学におりる数值計算. 日本航 空宇宙学会誌, 18 卷 197 号, pp. 234-243 (1970/6).

38) Murman, E. M. \& Cole, J. D. : Calculation of Plane Steady Transonic Flows. AIAA Jour. Vol. 9, No. 1 (Jan. 1971).

39) Krupp, J.A. \& Murman, E. M. : The Numerical Calculation of Steady Transonic Flows Past Thin Lif ting Airfoils and Slender Bodies. AIAA Paper 71-566 (1971)

40) Steger, J.L. \& Lomax, H.: Numerical Calculation of Transonic Flow About Two-Dimensional Airfoils by Relaxation Procedure. AIAA Paper 71-569 (1971)

41) Selrs, C. C. L. :Plane Subcritical Flow Past a Lifting Aerofoil. Proc. Roy. Soc. A. 308, pp. 371401 (1968).

42）たとえば Liepmann, H.W. \& Roshкo, A. : Elements of Gasdynamics. John Wiley \& Sons (1957), p. 98.

43) Lock, R.C.: Test Cases for Numerical Methods in Two-Dimensional Transonic Flows. AGARD Rep. No. 575 (1970). 